\title{
POVO E CIDADANIA NO ESTADO DEMOCRÁTICO DE DIREITO
}

\section{Eder Dion de Paula Costa}

Doutorando em Direito na UFPR, Professor da FURG/RS.

SUMÁRIO: Introdução; 1 O Conceito de Cidadania nos seus Primórdios; 2 O Conceito de Cidadania para os Teóricos do Liberalismo; 3 A Reação do Proletariado; 4 Sobre o Conceito de Povo; Considerações Finais; Referências Bibliográficas.

\section{INTRODUÇÃO}

A Constituição da República Federativa do Brasil de 1988 estabeleceu em seu art. $1^{\circ}$ os seus princípios fundamentais, os quais devem pautar a condução da sociedade brasileira. Desta forma, estamos constituídos num Estado Democrático de Direito que tem como fundamento a soberania, a cidadania, a dignidade da pessoa humana, os valores sociais do trabalho e da livre iniciativa e o pluralismo político, estando expresso que todo o poder emana do povo, que o exerce por meio de representantes eleitos ou diretamente, nos termos desta Constituição.

Dos referidos fundamentos, pretendemos nos ater mais detidamente aos conceitos de povo e de cidadania, ou seja, o que representam tais termos e quais as suas origens, o que poderá permitir compreender a razão de sua inserção no imaginário social.

\section{O CONCEITO DE CIDADANIA NOS SEUS PRIMÓRDIOS}

A compreensão que temos de cidadania não é a mesma de seus primórdios e de suas variações que sofreu ao longo do tempo. Assim, é necessário conhecê-la na sua perspectiva histórica e avaliar o seu real significado.

A origem do conceito político de cidadania ocorreu na Grécia antiga, onde este conceito era considerado para quem pertencesse a polis. ARISTÓTELES, na sua A política, esclarece a sua formulação de cidadão, em que a "sua qualidade verdadeiramente característica, é o direito de voto nas assembléias e de participação no exercício do poder público em sua pátria". ${ }^{1}$ A condição de cidadão estava sujeito a um processo seletivo, visto existir uma nítida separação entre cidadão e não-cidadãos, sendo estes últimos os escravos e/ou estrangeiros.

"O estado atual do regime apresenta a seguinte conformação: participam da cidadania os nascidos de pai e mãe cidadãos, sendo inscritos entre os démotas aos dezoito anos. Quando da inscrição, os démotas votam sob juramento a seu respeito: primeiro, se eles aparentam ter a idade legal (caso não aparentem, 
retornam novamente à condição de meninos); segundo, se é homem livre e de nascimento em conformidade com as leis e, caso o rejeitem por não se tratar de homem livre, ele pode apelar para o tribunal, ao passo que os démotas encarregam da acusação cinco de seus membros; se for considerado que a inscrição é indevida, o Estado o vende, mas se ele ganha, os démotas ficam obrigados a inscrevê-lo."²

A possibilidade de ser cidadão grego estava sujeita a pré-condições bem definidas, como era o caso de ser filho de pai e mãe cidadãos, pois do contrário eram tidos como estrangeiro ou escravo, e o de aparentar a idade de dezoito anos. Estes requisitos determinam a reprodução de um núcleo social seletivo que possui o privilégio na condução dos interesses políticos. Assim, o atributo da cidadania era um privilégio de uma pequena parcela da população. Na Atenas do comandante Péricles, no período aproximado do século V a.C., segundo o historiador inglês PERRY ANDERSON, o número de escravos giraria em torno de 80 a 100 mil, enquanto que o número de homens livres era em cerca de 45 mil.

O exercício da cidadania por um número reduzido de homens livres qualificados em comparação com a totalidade dos habitantes da cidade e do campo em seu conjunto, onde eles correspondiam aproximadamente a um sexto deste contingente, era base da democracia ateniense, a qual possuía algumas características que a diferenciava em muito da democracia moderna. A primeira característica fundamental era que as decisões eram tomadas de forma direta, sem representantes. O cidadão votava diretamente nas propostas apresentadas pelos oradores, sem interferências, sujeito tão-somente à sua consciência, fruto dos debates nas tabernas e do convencimento feito pelo orador na assembléia. A segunda característica é relativa ao espaço restrito da cidade-Estado grega, onde efetivamente se davam as decisões em assembléia. A terceira característica é que o sistema culminava na assembléia, a qual possuía o direito e o poder de tomar todas as decisões políticas, com poucas limitações na prática, seja de precedentes, seja do raio de ação. A quarta característica é a que diz respeito ao comportamento da massa em assembléia, a qual em nada se compara ao Parlamento moderno, seja em razão da alternância dos presentes na plenária e de sua grande quantidade.

A assembléia era o ponto alto da democracia grega, uma vez que era neste ambiente que se decidiam todas as questões internas e externas da política grega. Ela era aberta à participação de todos os cidadãos gregos, estando excluídos os escravos, as mulheres e os não-cidadãos, os quais que por uma razão ou outra perderam os seus direitos cívicos. MOSES FINLEY nos diz que:

"O comparecimento à assembléia soberana era aberto a todo cidadão, e não havia burocracia ou funcionários públicos, exceto alguns escravos de propriedade do Estado que faziam registros inevitáveis, como cópias de tratados e leis, listas de contribuintes inadimplentes e similares. O governo era, assim, pelo povo, no sentido mais literal. A assembléia, que detinha a palavra final na guerra e na paz, nos tratados, nas finanças, na legislação, nas obras públicas, 
em suma, na totalidade das atividades governamentais, era um comício ao ar livre, com tantos milhares de cidadãos com idade superior a 18 anos quantos quisessem comparecer naquele determinado dia. Ela se reunia freqüentemente durante o ano todo, no mínimo quarenta vezes, e, normalmente chegava a uma decisão sobre o assunto a discutir em um único dia de debate, em que, em princípio, todos os presentes tinham o direito de participar, tomando a palavra. Isegoria, o direito universal de falar na assembléia, era algumas vezes empregado pelos escritores gregos como sinônimo de democracia. E a decisão era pelo voto da maioria simples daqueles que estivessem presentes."3

MOSES FINLEY, em consonância com as estimativas de PERRY ANDERSON, acrescenta que no tempo de Péricles o número de cidadãos qualificados era cerca de 35 a 40 mil, mas destes, tem-se a estimativa de que apenas 1/3 compareciam. Isto faz sentido, uma vez em que seriam poucos os camponeses que fariam a viagem para comparecer a uma reunião da assembléia para deliberarem sobre questões que não fossem graves ou que não lhes dissessem respeito direto. Ocorreram exceções, como nos últimos dez anos da guerra do Peloponeso, em que toda a população foi compelida a abandonar o campo e viver dentro dos limites dos muros da cidade. Neste período, é óbvio, houve uma proporção maior de camponeses nas reuniões do que habitualmente ocorria.

A assembléia apresentava variações em sua composição, seja em decorrência da participação de um maior grupo em função de mobilização para deliberar sobre assunto de seu interesse ou ainda em razão de situações articuladamente preparadas para não comparecerem. Um exemplo do que acabamos de dizer nos é citado por FINLEY, o qual expressa que:

"Na ocasião, a assembléia foi terrorizada para votar a favor da abolição da democracia, e por certo não foi por acidente que isso aconteceu em uma ocasião em que a esquadra, completamente mobilizada, se encontrava na ilha de Samos. Os cidadãos que serviam na marinha vinham das classes mais pobres e eram conhecidos por serem os mais leias partidários do sistema democrático na forma que adquiriu no século V. Como estivessem em Samos, não poderiam estar em Atenas, permitindo, assim, que os oligarcas ganhassem através de uma maioria presente à assembléia que não era apenas uma minoria de membros qualificados, mas também uma minoria atípica."4

O modelo de cidadania grega bem demonstra que o poder decisório estava restrito a um contingente bastante limitado, isto já se considerando que o numero de cidadãos qualificados era por si só reduzido em relação ao numero de habitantes. Ou seja, dos poucos habitantes que possuíam o atributo da cidadania, menor era ainda o conjunto daqueles que efetivamente decidiam, visto que as deliberações decorriam da maioria simples presente na assembléia. Assim, é possível verificar que a cidadania grega,

3 FINLEY, Moses. Democracia antiga e moderna. Trad. Waldéa Barcellos e Sandra Bedran. Rio de Janeiro: Graal, 1988, p. 31. 
conforme o conceito aristotélico, que pressupõe o habitante qualificado como cidadão em condições de votar, estava resumido a uma parte deste conjunto que possuísse disposição para tais atividades.

Um outro aspecto a ser salientado era de que a divisão social na Grécia antiga se dava em função de um aspecto econômico e político, ou seja, os escravos eram os que davam a condição estrutural de subsistência e que, no entanto, não participavam das deliberações da pólis, e de outro lado estavam os cidadãos livres qualificados detentores da terra e dos meios de produção e que detinham o poder decisório. Assim, para JOSÉ WELMOWICKI, o homem que habitava a Grécia não era visto de forma igual, uma vez que "o homem livre econômico era também o homem livre político. A principal separação econômico-social entre homens livres e escravos era clara e diretamente refletida na definição da condição de cidadania política, e não oculta, como mais tarde iria se manifestar com o advento do capitalismo, onde essa separação seria distinta no homo economicus e no homem político".

A base econômica de produção da sociedade grega estava alicerçada no trabalho escravo, o que possibilitava ao cidadão livre dispor de tempo para a sua atuação política. A divisão de classes a partir das condições econômicas e políticas era a tônica da sociedade grega, conforme se pode vislumbrar no postulado por ARISTÓTELES:

"Ora, como vimos, é impossível separar a felicidade da virtude; portanto, é claro que num Estado tão perfeitamente constituído que não admita como cidadãos senão pessoas de bem, não apenas sob certos aspectos, mas integralmente virtuosos, não devemos contar entre os cidadãos aqueles que exercem profissões mecânicas ou comerciais, sendo esse gênero de vida ignóbil e contrário à virtude; nem mesmo os lavradores, pois é preciso mais lazer do que eles têm para adquirir virtudes e para o exercício dos cargos civis." ${ }^{\prime 6}$

Vislumbra-se na concepção de ARISTÓTELES que o trabalho escravo, o qual realizava grande parte do trabalho manual, muito mais do que uma necessidade era também uma questão de opção de organização social, visto que associa a busca da felicidade com a possibilidade de se alcançar a virtude, condição esta que somente é factível ao homem livre, que possui disponibilidade para o exercício de atividades civis. Além disto, este homem deve ter recursos suficientes que o liberem dos compromissos de subsistência e assim possa ter um maior envolvimento com as questões atinentes a pólis. Neste sentido, ARISTÓTELES complementa:

"Convém que os cidadãos tenham riquezas. Devem gozar de certa prosperidade, pois a cidadania não pode prostituir-se pelos trabalhadores manuais, nem por outras pessoas a quem a prática da virtude é desconhecida. Esta é uma conseqüência de nossos princípios. Como a virtude é indispensável para a felicidade, a felicidade do Estado não deve limitar-se a uma de suas

5 WELMOWICKI, José. O Discurso da Cidadania e a Independência de Classe. In: Rev. Koorkom. São Paulo: João Ricardo Soares, jun. 2000, p. 68.

6 ARISTÓTELES. A política. Trad. Roberto Leal Ferreira. São Paulo: Martins Fontes, 1991, p. 85 
partes, mas abarcar a universalidade dos cidadãos ou dos proprietários. Somente são verdadeiros cidadãos aqueles a que pertencem os imóveis, pois a simples cultura quase que só pode convir a pessoas de condição servil ou bárbara, assim como aos camponeses que por nascimento estão ligados à terra."

A propriedade dos bens, da terra, dos instrumentos que propiciam a produção e dos homens que estão naturalmente na condição de instrumentos animados e que devem manipular os instrumentos inanimados, tudo isto faz parte da propriedade doméstica assinalada por ARISTÓTELES, a qual deve pertencer por conveniência ao cidadão livre qualificado.

\section{O CONCEITO DE CIDADANIA PARA OS TEÓRICOS DO LIBERALISMO}

A superação do modelo feudal esteve sujeita a intensa luta travada por vários pensadores que visavam fundamentar uma nova teoria que viesse valorizar a individualidade, e neste caso, preferencialmente, a da burguesia ascendente que reclamava o seu espaço de dominação e começava a fazer frente à aristocracia e ao clero. Uma nova concepção de sociedade em que o direito à liberdade passa a ser reconhecido como um direito natural do indivíduo, e que esta liberdade está em consonância direta com o direito de propriedade, foi a formulação elaborada pelo médico e filósofo inglês, JOHN LOCKE, no século XVII, teórico da revolução liberal inglesa de 1689.

Charlo JOHN LOCKE dizia que o estado de natureza tem uma lei de natureza para governá-lo, que a todos obriga: e a razão, que é essa lei, ensina a todos os homens que tão-só a consultem, sendo todos iguais e independentes, que nenhum deles deve prejudicar a outrem na vida, na saúde, na liberdade ou nas posses. Neste estado o homem está em perfeita liberdade para ordenar-lhe as ações e regular-lhes as posses, dentro dos limites da lei da natureza, sem pedir permissão ou depender da vontade de qualquer outro homem.

LOCKE apresentava como justificativa para a existência do contrato entre os indivíduos, o qual era essencial para a formação da sociedade e do Estado, a de prevenir o estado de guerra. Este tipo de situação era para LOCKE um estado de inimizade e destruição, que declara desígnio inalterável e calmo com relação à vida de outrem. Assim, quando alguém tenta colocar outrem sob poder absoluto, põe-se em estado de guerra. Isto permite que aquele que sofreu a coação possa reagir e inclusive retirar a vida deste agressor, ainda que este tenha somente lhe retirado o dinheiro.

O estado de guerra era assim um forte argumento contra a imposição do senhor feudal, dono das terras e das pessoas, juiz e promotor dos conflitos, o que dificultava o livre comércio e a segurança dos negócios realizados pela burguesia, a qual precisava de garantias para os seus investimentos. Além da afirmação do conceito de necessidade do contrato entre indivíduos livres, era imperioso neste sentido que a propriedade fosse 
requisito indispensável para a existência da noção de liberdade, razão pela qual propriedade e liberdade eram características do indivíduo livre.

O teórico do liberalismo afirmava que embora a terra e todas as criaturas inferiores fossem comum a todos os homens, cada homem possui uma propriedade em sua própria pessoa, sendo que a esta ninguém tem qualquer direito senão ele mesmo. $\mathrm{O}$ homem, retirando do estado comum o que a natureza colocou, anexou-lhe por esse trabalho algo que o exclui do direito comum dos outros, e assim, sendo propriedade exclusiva do trabalhador, ninguém lhe pode retirar.

LOCKE diz que a principal matéria da propriedade não são os frutos da terra e os animais que sobre ela subsistem, mas a própria terra, como aquilo que abrange e consigo leva tudo o mais, o que lhe faz pensar ser evidente que aí também a propriedade se adquire como nos outros casos. Assim, a extensão da terra que um homem lavra, melhora, cultiva e cujos produtos usa, constitui a sua propriedade. Pelo trabalho, por assim dizer, separa-a do comum. Nem lhe invalidará o direito dizer que qualquer outro terá igual direito a essa extensão de terra, não sendo possível, portanto, àquele apropriarse ou fechá-la sem o consentimento de todos os membros da comunidade - todos os homens.

Para JOHN LOCKE, é através do trabalho que se estabelece a diferença de valor em tudo quanto existe. Neste sentido, exemplifica com o fato de que se considere uma terra comum sem nenhum beneficiamento em comparação com outra em que tenha sido plantado trigo, arroz ou qualquer outra cultura se verificará que esta última tem um valor maior que a primeira, o qual decorre do trabalho realizado. O trabalho, ou melhor, o uso da terra, era a forma de se adquirir a propriedade da terra, algo que somente seria possível a quem detivesse recursos para beneficiar a maior extensão possível. O trabalhador, que nada possuía e nem meios para realizar tal beneficiamento da terra, tinha a possibilidade de alienar a sua força de trabalho, a qual era sua propriedade, e assim, através do contrato, legitimava a expropriação que sofria.

Segundo JOSÉ WELMOWICKI, a formulação teórica de LOCKE era no sentido de combater os privilégios feudais e a defesa da propriedade burguesa contra os ataques arbitrários dos reis e da nobreza, o que em certo sentido também delimitava os parâmetros de cidadania para a nova sociedade. ${ }^{8}$ A promíscua relação entre propriedade e trabalho definia que o detentor de recursos poderia apropriar-se, através do trabalho, de vasta extensão de terra, e o outro que nada possuía, geralmente o antigo servo da gleba, poderia alienar a sua força de trabalho, já que não teria meios de beneficiar a terra. Assim, sendo a liberdade, em última instância, o direito à propriedade, os homens livres são aqueles que detêm a propriedade, neste caso a burguesia, sendo que o trabalhador, proprietário da sua força de trabalho, ao aliená-la, despiu-se de sua propriedade.

JOHN LOCKE teve a preocupação de justificar a posse e exploração da terra de forma diferenciada, ou seja, por aqueles que detinham recursos para tal. Primeiro 
expressava o fato de que alguns homens não eram bastante operosos no beneficiamento da terra, preferindo o lazer, razão pela qual a terra ociosa deveria ser apropriada por quem tivesse disposição. Em segundo, reflete o sentido da utilidade no aproveitamento da terra, isto é, de nada adianta cultivar além do necessário para a sua subsistência, quando o excedente perecerá. Assim, diz que a troca do excedente pelo ouro e o uso do dinheiro justificavam a legítima extensão da propriedade.

"Ainda mais, se trocasse as nozes por um bocado de metal, cuja cor lhe agradasse, ou os carneiros por conchas ou a lã por uma pedra cintilante ou um diamante, e guardasse esses objetos durante toda a vida, não invadiria os direitos de terceiros; poderia acumular qualquer quantidade que quisesse desses objetos duradouros; não se achando o extremo dos limites da sua justa propriedade na extensão do que possuía, mas no perecimento de tudo quanto fosse inútil a ela. E assim, originou-se o uso do dinheiro - algo de duradouro que os homens pudessem guardar sem estragar-se, e que por consentimento mútuo recebessem em troca de sustentáculos da vida, verdadeiramente úteis, mas perecíveis."

Na continuação da justificativa da justa extensão da propriedade, LOCKE afirma esta possibilidade através de um consenso entre todos os homens, em que todos aceitariam e entenderiam como um direito natural e, portanto, justo, da livre apropriação da terra através do trabalho. No entanto, o que se vislumbrou, em verdade, é que aqueles que se apropriaram da terra em excesso, assim o fizeram porque possuíam recursos para tal fim, enquanto que os destituídos de posse eram obrigados a alienar o seu trabalho para outrem, visto que não possuíam condições de beneficiar e apropriar a terra para si próprios.

"Mas como o ouro e a prata são de pouca utilidade para a vida humana em comparação com o alimento, vestuário e transporte, tendo valor somente pelo consenso dos homens, enquanto o trabalho dá grande parte a medida, é evidente que os homens concordaram com a posse desigual e desproporcionada da terra, tendo descoberto, mediante consentimento tácito e voluntário, a maneira de um homem possuir licitamente mais terra do que aquela cujo produto pode utilizar, recebendo em troca, pelo excesso, ouro e prata que podem guardar sem causar dano a terceiros, uma vez que estes metais não se deterioram nem se estragam nas mãos de quem os possui. Os homens tornaram praticável semelhante partilha em desigualdade de posses particulares fora dos limites da sociedade e sem precisar de pacto, atribuindo valor ao ouro e à prata, e concordando tacitamente com respeito ao uso do dinheiro; porque, nos governos, as leis regulam o direito de propriedade e constituições positivas determinam a posse da terra." 10

Para WELMOWICKI, ficou fácil deduzir qual a origem da concepção do voto censitário, o direito ao voto somente àqueles que têm um determinado rendimento ou propriedade. Assim, a existência de uma sociedade que preza pela garantia da

9 LOCKE, John. Segundo tratado sobre o governo. Trad. Anoar Aiex e E. Jacy Monteiro. São Paulo: Abril, 1978, p. 52. Coleção os Pensadores.

10 Idem, p. 53. 
propriedade privada e que dá primazia à presença de uma instância de deliberação formada apenas por indivíduos (ou cidadãos) que têm acesso a determinada forma de propriedade ou riqueza, são características que dão suporte para a reprodução e sustentação da burguesia ascendente. WELMOWICKI faz interessante referência à obra de KARL MARX, de que ...

“... do lado capitalista, na propriedade revela-se o direito de apropriar-se de trabalho alheio não pago ou do seu produto, e, do lado do trabalhador, a impossibilidade de apropriar-se do produto de seu trabalho. A dissociação entre propriedade e trabalho é conseqüência necessária de uma lei que claramente derivava da identidade existente entre ambos."

A concepção do individualismo foi fundamental para a burguesia enfrentar a aristocracia e superar o sistema feudal. Neste sentido, um importante estudo realizado por C. B. MCPHERSON, professor de Ciência Política na Universidade de Toronto, que procurou estabelecer a utilidade da noção de individualismo possessivo como hipótese central das teorias políticas liberais. MCPHERSON em sua A Teoria Política do Individualismo Possessivo, obra que faz uma análise das teorias de HOBBES a LOCKE, apresenta sete proposições que tentam expressar as suposições compreendidas pelo individualismo possessivo e que de certa forma são algumas das suposições sociais identificáveis e que são comuns às principais teorias políticas do século XVII:

"1) o que confere aos seres o atributo de humanos é a liberdade de dependência da vontade alheia;

2) a liberdade da dependência alheia significa liberdade de quaisquer relações com outros, menos as relações em que os indivíduos entram voluntariamente visando o seu próprio proveito;

3) o indivíduo é essencialmente o proprietário de sua própria pessoa e de suas próprias capacidades, pelas quais ele não deve nada à sociedade;

4) se bem que o indivíduo não possa alienar a totalidade de sua propriedade de sua própria pessoa, ele pode alienar sua capacidade de trabalho;

5) a sociedade humana consiste de uma série de relações de mercado;

6) já que a liberdade das vontades dos outros é o que torna humano o indivíduo, a liberdade de cada indivíduo só pode ser legitimamente limitada pelos deveres e normas necessários para garantir a mesma liberdade aos outros;

7) a sociedade política é um artifício humano para a proteção da propriedade individual da própria pessoa e dos próprios bens, e (portanto), para a manutenção das relações ordeiras de trocas entre os indivíduos, considerados como proprietários de si mesmos."12

11 WELMOWICK, José. Op. cit., p. 69. O texto citado refere-se à obra de KARL MARX: O capital. 8. ed. São Paulo: Difel, v. 2, livro I, 1982, p. 679.

12 MCPHERSON, C. B. Teoria política do individualismo possessivo de Hobbes até Locke. Trad. Nélson Dantas. Rio de Janeiro: Paz e Terra, 1979, p. 275-276. 
Outro importante teórico do individualismo e que apresenta uma concepção democrático-burguesa é JEAN-JACQUES ROUSSEAU (1712-1778), para quem os homens nascem livres e iguais, mas em todo o lugar estão acorrentados. Ele faz uma crítica à descrição feita por HOBBES sobre o homem natural, que era na verdade a descrição do homem do seu tempo, que estava acorrentado e oprimido pela civilização. Assim, para ROUSSEAU, a única forma de o homem se libertar de tal situação é através do contrato social, onde cada um expressa a sua vontade e que será representada pela vontade geral.

ROUSSEAU diz que existe uma condição natural dos homens, que é a de felicidade, virtude e de liberdade, as quais são destruídas e apagadas pela civilização. A sua igualdade é aquela diante da lei, ou seja, a da igualdade jurídica. A compreensão de ROUSSEAU sobre a sociedade é moldada no individualismo burguês: a propriedade resultaria de uma relação entre indivíduos, ou seja, da iniciativa de um indivíduo. Assim, é na base do individualismo burguês que está a base de formação da propriedade. Em seu contrato social se observa que a soberania é do povo, pois sendo esta quem detém a vontade geral, é somente quem poderá lhe impor limites. O único órgão soberano neste caso é a assembléia.

ROUSSEAU, na sua obstinada contrariedade com o antigo regime, denunciava que os homens estavam divididos entre cidadãos e súditos, sendo que estes, na condição de subjugados, eram os desprovidos de títulos e de família nobre, tendo que obedecer aos nobres e reis. Como forma de garantir a liberdade do homem, ROUSSEAU entendia que se deveria promover a igualdade jurídica, e assim todos se transformariam em cidadãos, não ocorrendo mais diferenças em razão de títulos ou da família.

A proposta de ROUSSEAU de uma cidadania universal esbarrou na limitação dada pela burguesia, que embora levantando a bandeira da Revolução Francesa, Liberdade, Igualdade e Fraternidade, não cumpriu este lema ao pé da letra. Na primeira Constituição pós-revolução (1791), já se verificava a limitação imposta, ou seja, era estabelecida a divisão entre cidadãos passivos e ativos, sendo garantido a estes o direito de votar e serem votados, e os primeiros, de acordo com um critério de rendimentos, não poderiam fazê-lo. Assim, estava inserido o voto sob o critério censitário.

Importante salientar, que da mesma forma que ocorria uma limitação na concepção de uma cidadania universal, o mesmo se verificava em relação à Declaração dos Direitos do Homem e do Cidadão, de tal sorte que, ao expressar uma série de preceitos democráticos, colocava no mesmo patamar o inviolável direito de propriedade. WELMOWICKI, em sua peculiar investigação, diz que "os direitos do cidadão paravam no limite sagrado do direito individual à propriedade. Apesar da abolição dos privilégios da nobreza e do clero, continuava a haver uma profunda desigualdade social, que partia do antagonismo em relação à propriedade dos meios de produção. Enquanto uma grande maioria não tinha a posse dos mesmos, uma minoria, a burguesia, não só detinha seu monopólio, como utilizava a mão-de-obra dos despossuídos para garantir a produção de mercadorias e extrair o lucro". ${ }^{13}$ 
A luta pelo fim do sistema feudal era de especial interesse para a burguesia ascendente, uma vez que o direito existente era aquele dominado pela nobreza e pelo clero. A queda deste modelo permitiria um novo modelo jurídico, de valorização do indivíduo com a criação da cidadania e do sujeito de direito. No entanto, o que se viu é que o indivíduo livre era de duas categorias, ou seja, um que era o cidadão ativo, sujeito de direito com liberdade para contratar e explorar, detentor dos meios de produção, e o outro, na condição de cidadão passivo e sujeito de direito com liberdade para alienar a sua força de trabalho.

Com a superação do modelo feudal de produção e a ascensão da revolução industrial se criou a figura do sujeito de direito. Assim, nos perguntamos por que o sujeito de direito é uma criação do modo de produção capitalista? Para que possamos obter uma resposta satisfatória a esta indagação é necessário que saibamos por primeiro como se dá o modo de produção capitalista. Este ocorre com o processo de valorização de um capital por meio de uma força de trabalho comprada num mercado como mercadoria: a compra da força de trabalho toma a forma de um salário, que é suposto representar o equivalente dispêndio dessa força de trabalho. Com efeito, o salário não representa o equivalente dispêndio da força de trabalho, mas uma parte dele tão-somente. A parte não paga do dispêndio da força de trabalho valoriza, no entanto, o capital, fazendo-o produzir um rendimento, a mais-valia, de que se apropria o proprietário do capital. Para que haja capital é preciso que ele seja valorizado - que ele "produza filhos" na fórmula de MARX - quer dizer, é preciso que ele compre no mercado uma mercadoria particular: a força de trabalho, mercadoria que tem a particularidade de criar o valor.

Em razão da aplicação da mais-valia, tem o capitalista a necessidade de um exército suplementar de mão-de-obra que possa fazer uso. Assim, é preciso desmontar o modelo feudal, que mantém uma tradição de solidariedade, hierarquia e submissão. Para isto, é implementado um modelo de propriedade privada em que os trabalhadores do campo são expulsos para as cidades, formando assim o proletariado. Com um grande contingente nas cidades, o antigo modelo de parentesco passa por um processo de esfacelamento, uma vez que a atividade passa a ser individualizada, autônoma, não tendo mais o vínculo familiar e coletivo. O caráter de solidariedade que era inerente às atividades campesinas foi, propositadamente, atenuado, uma vez que o modo de produção capitalista supõe, pois, como condição do seu funcionamento a "atomização", quer dizer, a representação ideológica da sociedade como um conjunto de indivíduos separados e livres. Esta representação, no plano jurídico, toma a forma de sujeito de direito, e no plano político, o de cidadão.

\section{A REAÇÃO DO PROLETARIADO}

Com a crescente pauperização da classe trabalhadora que abarrotava as grandes cidades européias, a reação deste contingente humano que era explorado à exaustão ocorreu de forma intensa. $\mathrm{O}$ aspecto fundamental a ser verificado era de que o trabalhador deveria se enxergar como integrante de uma classe, não mais como indivíduo, na perspectiva burguesa, mas como um coletivo que possuía uma identidade de 
reivindicações frente à classe dominante. JOSÉ WELMOWICKI diz que "foram MARX e ENGELS, a partir de seu intenso contato com o movimento operário nascente e sua ruptura com o hegelianismo, que começaram a elaborar uma ciência política a partir do ponto de vista do proletariado, uma visão assumidamente de classe". ${ }^{14}$ As análises feitas por MARX e ENGELS refletiam o aspecto de que a chamada igualdade jurídica, meramente formal, que existiria entre todos os indivíduos chamados de sujeitos de direito ou de cidadãos, escamoteava na verdade uma profunda diferença de classes sociais e isto demonstrava o eixo fundamental na definição dos interesses distintos que se chocavam.

A luta de classes defendida por MARX através da sua ditadura do proletariado representa o esforço contínuo que deve ser feito pela classe trabalhadora, enquanto um coletivo que possui uma identidade própria, no enfrentamento à burguesia, que possui interesses notadamente divergentes dos proletários. Assim, para MARX, a noção de cidadania passa a ser uma categoria abstrata, desligada da práxis real e dos conflitos inerentes à sociedade capitalista, visto que se opõe à real identidade de classe.

A reação da classe trabalhadora frente à exploração que reinava nas relações de trabalho de então teve uma importante expressão através da organização sindical, a qual, durante muito tempo, sofreu uma contínua repressão, como foi o caso da lei Le Chapelier. Essa lei recebeu esse nome em referência ao relator da comissão constituída para o estudo do problema e que formulou as seguintes conclusões:

"1) as corporações que se formaram tiveram por fim aumentar o preço da jornada de trabalho, impedir as livres convenções entre os particulares, fazendoos concordar com contratos de adesão em ameaça à ordem pública;

2) não deve haver mais corporações no Estado e no seu lugar deve existir apenas o interesse particular de cada indivíduo;

3) impõe-se a necessidade de uma convenção livre de indivíduo para indivíduo para fixar a jornada de trabalho de cada trabalhador;

4) indispensável se tornava uma lei para coibir esses abusos."

Esta a fundamentação da lei Le Chapelier, e conforme se verifica, a ação coletiva dos chamados cidadãos não se coadunava com a perspectiva burguesa de cidadania baseada na liberdade de contratação do indivíduo, sem distinção de classes. Assim é o que se observa no escopo da lei:

"A eliminação de toda espécie de corporação de cidadãos do mesmo estado ou profissão é uma das bases essenciais da Constituição Francesa, ficando proibido o seu restabelecimento sob qualquer pretexto e sob qualquer forma;

Os cidadãos do mesmo estado social ou profissão, os obreiros e companheiros de uma arte qualquer, não poderão, quando se reunirem, designar 
presidente, secretário, ou síndico, lavrar registros, tomar resoluções, sancionar regulamentações sobre seus pretensos direitos comuns;

Fica proibido a todas as corporações administrativas ou municipais receber qualquer solicitação ou petição sob o nome de um estado social ou profissão, nem poderá respondê-la; estão obrigadas a declarar nulas as resoluções que forem tomadas."

A Lei Le Chapelier influenciou toda a Europa, e, somente em 1824, na Inglaterra, é aprovado um projeto dando existência legal aos sindicatos e em 1834 é fundada a união dos Grandes Sindicatos Nacionais Consolidados, congregando meio milhão de trabalhadores, a qual foi inspirada por ROBERT OWEN. JOSÉ WELMOWICKI nos diz que "desde as últimas décadas do século XIX e em todo o transcorrer do século XX, o cenário para o movimento operário da Europa Ocidental capitalista havia se modificado com as conquistas sociais, democráticas e trabalhistas arrancadas nos principais países europeus até a Primeira Guerra Mundial, entre elas a jornada de 8 horas, o reconhecimento dos sindicatos de massa, o direito de voto e a organização e legalização dos grandes partidos socialistas ou laboralistas". ${ }^{15}$

As conseqüências do colapso econômico entre as duas grandes guerras foram terríveis, como foi o caso da Alemanha, onde a crise do sistema monetário atingiu o seu pior patamar em 1923, e a sua unidade monetária foi reduzida a um milionésimo de milhão de seu valor de 1913. Com isto, conforme PLAUTO DE AZEVEDO, as poupanças privadas desapareceram, criando um vácuo quase completo de capital ativo para as empresas, passando a economia alemã a depender de empréstimos estrangeiros de grande vulto. PLAUTO FARACO AZEVEDO, valendo-se da obra de HOBSBAWN, a Era dos Extremos, afirma ser este um dos dados fundamentais para a ascensão do nazismo. ${ }^{16}$

A ascensão do nazismo em decorrência de sua crise monetária, o desemprego que se alastrava em toda a Europa e um quadro geral agravado em decorrência da quebra da Bolsa de Nova Iorque em 29 de outubro de 1929, aprofundaram a crise econômica, tornando-a universal. O modelo da economia liberal de então, que tinha em ADAM SMITH o seu grande teórico e que propunha a liberdade de mercado do "deixar fazer", não era capaz de solucionar a aflitiva situação da economia mundial. A preocupação de ADAM SMITH era com a organização dos trabalhadores, devendo esta ser impedida, sendo que cada cidadão, como indivíduo, teria a obrigação de buscar sua melhor recompensa no mercado.

"As pessoas da mesma profissão raramente se reúnem, mesmo que seja para momentos alegres e divertidos, mas as conversações terminam em uma conspiração contra o público, ou em algum incitamento para aumentar os preços. Efetivamente, é impossível evitar tais reuniões, por meio de leis que

16 AZEVEDO, Plauto Faraco. Direito, justiça social e neoliberalismo. São Paulo: Revista dos Tribunais, 2000 , p. 86 
possam ser cumpridas e se coadunem com o espírito de liberdade e justiça. Todavia, embora a lei não possa impedir as pessoas da mesma ocupação de se reunirem às vezes, nada se deve fazer no sentido de facilitar tais reuniões e muito menos torná-las necessárias." 17

A crise econômica atingiu todos os setores, tanto das manufaturas como produção básica, como no caso dos alimentos e de matérias-primas, porque os preços, não mais mantidos pela formação de estoques, entraram em queda livre. A Europa e a América estavam numa situação de penúria, sendo pior ainda para os desempregados, uma vez que a previdência pública, na forma de seguro social, inclusive auxílio-desemprego, ou não existia, como nos Estados Unidos, ou, pelos padrões de fins do século XX, era parca, sobretudo para os desempregados a longo prazo. ${ }^{18}$ Com a crise avassaladora que estava instalada, nos países capitalistas, era necessário, para a burguesia, como forma de superar o descontentamento geral que ocorria, canalizar o furor das massas em seu benefício, como forma de estabilizar o regime na Europa e assegurar a recomposição dos estados capitalistas abalados pela guerra e os movimentos de massa em luta armada contra o nazi-fascismo. ${ }^{19}$ Assim é que muitas das reivindicações da classe trabalhadora passaram a ser concedidas. Foi aplicado o chamado plano Marshall, que era uma política de financiamento direcionada aos novos governos europeus, com vistas a que pudessem reconstruir sua economia arrasada e proceder às reformas sociais do assim chamado Welfare State.

A proposta de MARSHALL tinha a perspectiva de demonstrar que não haveria uma contradição entre uma política de universalização progressiva de direitos sociais e a lógica do sistema capitalista. Neste sentido, é o que se verifica na análise de PIETRO BARCELLONA em seu texto A Estratégia Improvável da Cidadania, conforme citação de WELMOWICKI, onde expõe "que o centro da noção de cidadania em MARSHAL é atribuir a essa categoria um novo significado - de acesso dos membros da comunidade a direitos sociais básicos que permitam integrar os setores mais pobres à sociedade, dar-lhes um sentido de inclusão, à medida que no próprio status de cidadão, estejam incorporados determinados direitos sociais e isso possa diminuir a desigualdade social". ${ }^{20}$

Os benefícios decorrentes do plano Marshall, como o alastramento dos direitos sociais, denotam, por um lado, a concessão que a burguesia permitiu à classe trabalhadora como forma de garantir, no difícil período do pós-guerra, um equilíbrio e sustentação do regime capitalista, e, de outro, permitiram a negação do reconhecimento de que os chamados direitos sociais teriam sido conquistas da classe trabalhadora. A dicotomia concessão/negação do chamado plano Marshall denota em seu âmago toda a contradição da proposta, visto que, ao conceder direitos, nega, ao mesmo tempo, que estes tenham

17 WELMOWICKI, José. Op. cit., p. 69.

18 AZEVEDO, Plauto Faraco. Op. cit., p. 87.

19 WELMOWICKI, José. Op. cit., p. 75.

20 Idem, p. 76 
sido resultados da luta, mas sim da bondade de quem domina, como um gesto de generosidade a demonstrar quem efetivamente manda, cabendo ao outro obedecer, subordinar-se. Não existe nessa proposta a possibilidade de igualdade, uma vez que hoje, conforme afirma WELMOWICKI, nos tempos do neoliberalismo, reaparece com toda a crueza a contradição entre uma idéia de progressiva cidadania social cada vez mais estendida e a realidade imposta pela lógica do mercado na sociedade capitalista. ${ }^{21}$

\section{SOBRE O CONCEITO DE POVO}

O termo povo tem conceituação recente, visto que a sua designação correspondia a muitas outras palavras sinônimas, mas que, no entanto, tinham a sua especificidade. Uma destas confusões é em relação ao termo nação, o qual, não possuindo também uma unanimidade na sua definição, diverge do conceito de povo, por denotar como um de seus elementos essenciais à origem étnica, ou seja, a unidade de estirpe. A nação é um agrupamento de origem natural e seu histórico é anterior ao Estado, sendo para SAHID MALUF "um conjunto homogêneo de pessoas ligadas entre si por vínculos permanentes de sangue, idioma, religião, cultura e ideais". Para PAULO BONAVIDES, do ponto de vista sociológico existe uma equivalência entre o conceito de povo e o de nação. Assim, o povo seria compreendido como toda a continuidade do elemento humano, projetado historicamente no decurso de várias gerações e dotado de valores e aspirações comuns. ${ }^{22}$

Diverge igualmente de povo o conceito de população, o qual tende a expressar um conceito aritmético, demográfico, isto é, a quantidade de indivíduos, o número total de habitantes que se encontram em determinado país ou região, sem exclusão dos estrangeiros, apátridas, dos súditos coloniais etc. ... ${ }^{23}$ Tem que se considerar que é fundamental a existência do elemento pessoal para que haja o Estado, decorrendo daí a estreita relação jurídica que deve coexistir entre o que chamamos de povo e o Estado.

DALMO DE ABREU DALLARI procura dar uma conceituação de povo segundo uma concepção atual do termo, conforme se verifica a seguir:

“... deve-se compreender como povo o conjunto dos indivíduos que, através de um momento jurídico, se unem para constituir o Estado, estabelecendo com este um vínculo jurídico de caráter permanente, participando da formação da vontade do Estado e do exercício do poder soberano. Essa participação e este exercício podem ser subordinados, por motivos de ordem prática, ao atendimento de certas condições objetivas, que assegurem a plena aptidão do indivíduo. Todos os que se integram no Estado, através da vinculação jurídica permanente, fixada no momento jurídico da unificação e da constituição do Estado, adquirem a condição de cidadãos, podendo-se, assim, conceituar o povo como o conjunto dos cidadãos do Estado. Dessa forma, o indivíduo que, 
no momento mesmo de seu nascimento, atende aos requisitos fixados pelo Estado para considerar-se integrado nele, é, desde logo, cidadão. Mas, como já foi assinalado, o Estado pode estabelecer determinadas condições objetivas, cujo atendimento é pressuposto para que o cidadão adquira o direito de participar da formação da vontade do Estado e do exercício da soberania. Só os que atendem àqueles requisitos e, conseqüentemente, adquirem estes direitos, é que obtêm a condição de cidadãos ativos."

É assim o povo, elemento indispensável na formação do Estado, o qual representa a substância, o recheio de uma estrutura formal perante a sociedade internacional. Neste sentido, podemos vislumbrar que, sendo o povo fundamental para a existência do Estado, é natural que este Estado seja um garantidor dos direitos individuais e coletivos de seu povo.

Segundo PAULO BONAVIDES, somente o direito pode explicar plenamente o conceito de povo, e isto muito em razão do vínculo que as pessoas têm de forma institucional e estável a um determinado ordenamento jurídico. Neste sentido, é interessante verificar a íntima relação entre povo e cidadania, conforme se verifica nos conceitos de vários autores citados por PAULO BONAVIDES. Segundo ORESTE RANELETTI, o povo é "o conjunto de indivíduos que pertencem ao Estado, isto é, o conjunto de cidadãos". Para GIANCARLO OSPITALI, povo é "o conjunto de pessoas que pertencem ao Estado pela relação de cidadania", ou ainda, no dizer de PIETRO VIRGA, como "o conjunto de indivíduos vinculados pela cidadania a um determinado ordenamento jurídico". ${ }^{24}$

A relação entre cidadania e povo é visto por BONAVIDES como a necessidade de se estabelecer uma identidade, sendo que a cidadania seria nesta relação específica a prova de identidade que mostra o vínculo do indivíduo com o Estado. Assim, é mediante essa relação que uma pessoa constitui fração ou parte de um povo. Diz ainda BONAVIDES, que o status civitatis ou estado de cidadania define basicamente a capacidade pública do indivíduo, a soma dos direitos políticos e deveres que ele tem perante o Estado. ${ }^{25}$

O estado de cidadania que define a capacidade pública do indivíduo, como a soma dos direitos políticos e deveres que ele tem perante o Estado, ou seja, o direito de votar e ser votado ou os deveres de fidelidade à pátria, prestação do serviço militar e observância das leis do Estado, demonstra, na verdade, que o povo, enquanto cidadão, deve concordar com as regras impostas e que são ditas por uma classe dominante.

A divisão de classes é algo que ainda se vislumbra na sociedade atual, notoriamente pelo que se verifica pela permanente exploração capitalista, sendo utópico imaginar que estaria sendo superado pela idéia de cidadania, nos moldes burgueses, de concordância entre as classes sociais e de uma igualdade formal dos indivíduos. PAULO BONAVIDES diz que não há democracia sem participação. De sorte que a participação 
é força que vitaliza a democracia e lhe assina o grau de eficácia e legitimidade no quadro social das relações de poder, bem como a extensão e abrangência desse fenômeno político numa sociedade repartida em classes ou em distintas esferas e categorias de interesses.

A participação do povo como um todo, e não somente no que se refere a uma compreensão de cidadania como esfera que delimita a capacidade do indivíduo enquanto agente de deliberação na esfera política, é a preocupação de FRIEDRICH MÜLLER, quando expressa que nem a todos os cidadãos é permitido votar e que nem todos os eleitores votam efetivamente. Questiona, ainda, o fato de como legitimar a minoria que é vencida pela maioria nas eleições e posteriores atos legislativos, e bem como quem é o "povo" que se esconde atrás dos efeitos informais sobre a formação da opinião pública e da vontade política do "povo", efeitos estes como as de pesquisas de opinião pública e das atividades associativas e corporativas podem produzir na política. ${ }^{26}$

Compreendendo que a cidadania não pode estar aferida pelos moldes burgueses, e sim dentro de uma perspectiva universal e de emancipação, é que se justifica a intensa participação popular. Neste diapasão, MÜLLER questiona o fato de que, se uma Constituição recorre ao poder constituinte do povo ou se ela atribui todo poder (de Estado) ao povo, será que esta se referindo à realidade? Claro que não. No entanto, diz que é possível reduzir esta distância entre a lei fundamental e a realidade, com os meios possíveis para uma constituição burguesa (visto que a aristocracia e o clero não estão no poder, e muito menos o proletariado). Isto se daria por intermédio de formas de legislação popular democrática sem mediações, da elegibilidade dos funcionários públicos e dos juízes, por intermédio da participação decisiva do povo em partidos e associações, concretamente normatizada. ${ }^{27}$

NORBERTO BOBBIO, ao tratar da participação popular num estado democrático, salienta que, "hoje, quem deseja ter um bom indicador do desenvolvimento democrático de um país deve considerar não mais o número de pessoas que têm direito de votar, mas o número de instâncias diversas daquelas tradicionalmente políticas nas quais se exerce o direito de voto. Em outras palavras, quem deseja dar um juízo sobre o desenvolvimento da democracia num dado país deve pôr-se não mais a pergunta quem vota? mas onde se vota?" ${ }^{28}$ Uma democracia efetiva não pode ser na sociedade atual apenas o resultado de um espectro de representantes, os quais, em sua maioria, não mais representam o povo, ou, ainda, no sentido reduzido, o cidadão eleitor; representam, na verdade, os seus interesses. Assim, a ampliação de um conceito de cidadania, que possa conduzir a uma igualdade substancial, decorre de uma efetiva participação popular nas suas mais diversas instâncias.

26 MÜLLER, Friedrich. Quem é o povo? A questão fundamental da democracia. Trad. Peter Naumann. São Paulo: Max Limonad, 1998, p. 49.

27 Idem, p. 50

28 BOBBIO, Norberto. Estado, governo e sociedade, para uma teoria geral da politica. Rio de Janeiro: Paz e Terra, 1992, p. 157. 
Um exemplo atual de ampliação da participação popular é o que ocorre na cidade de Porto Alegre/RS com a implementação do Orçamento Participativo. A definição de receitas e despesas é deliberada através da participação de cada pessoa presente nas assembléias de cada região do município, a qual será fiscal na implementação das propostas aprovadas. O mesmo vem ocorrendo em nível estadual, com assembléias nas 22 regiões, onde são definidas as prioridades na aplicação dos recursos. A participação do povo como um todo e em todas as esferas de deliberação que um Estado democrático deve propiciar e ampliar permite vislumbrar uma nova conceituação de cidadania, que não está restrita e delimitada por uma ordem jurídica burguesa, mas sim, dentro de uma perspectiva de democracia participativa.

A participação do povo ocorre com a sua ascensão e qualificação à condição de cidadão. No entanto, esse cidadão sofre as limitações que são impostas por uma concepção de construção burguesa, na qual é percebido tão-somente em sua individualidade genérica e na quantidade que representa. Assim, neste sentido, este indivíduo deixa de pertencer a uma classe distinta, como se fosse possível ocorrer uma superação da divisão social de classes com a sua ascensão ao título de cidadão e tornarse um igual ao integrante da burguesia. No entanto, este indivíduo genérico, por não se achar em condições de contrariar o status quo reinante, menospreza a sua participação crítica e opta pela obediência a quem exerce a dominação.

A crítica que é feita ao modelo de cidadania burguesa pelos teóricos marxistas reflete a impossibilidade de uma efetiva participação popular em razão de que não interessa à classe dominante o exercício de uma cidadania crítica, a qual poderia ser capaz de questionar o sistema em vigor. Assim, GRAMSCI alerta para o fato de que a disciplina burguesa preza pela indiferença da maioria, por uma obediência sem adesão, em que nessa democracia o que interessa é o número, a quantidade, como elemento essencial.

"Para atrair os jovens (...) bastaria que os círculos católicos representassem, para eles uma necessidade do espírito, a necessidade de estar juntos entre companheiros de ideal e de luta, e a consciência de que é um dever difundir e propagandear a fé que se vive como verdade única a afirmar a qualquer preço. (...) Juventude decrépita, a católica, que tendo perdido todo calor interno busca em arranjos práticos (...) saturar-se de associados; não importa que a maioria seja um peso morto (...) basta que entra no círculo como poderia entrar em uma associação esportiva (...) Basta que na ocasião possam exibir-se centenas de assinaturas (...) para protestar contra uma estátua de mulher nua ou contra a exposição de jornais pornográficos." ${ }^{29}$

A disciplina burguesa utiliza, desta forma, a quantidade abstrata e a individualidade genérica como elementos essenciais, visto que o primeiro seria o elemento de pressão, como se bastasse isso para que as vontades se fizessem ação, e o segundo, ao apagar as diferenças classistas, reduz operários, camponeses e burgueses à 
condição de homens iguais. Assim, a partir do instante que esses homens, cidadãos são pensados como indivíduos, é preciso apenas somá-los. A quantidade abstrata e a individualidade genérica são duas faces do mesmo mecanismo de ocultamento das vontades reais, concretas. Com isto, dissolvem-se também os vínculos de participação real, de concreção das vontades na história real. ${ }^{30}$

Segundo o Prof. EDMUNDO F. DIAS, nas suas reflexões sobre a obra de GRAMSCI, a realização da disciplina socialista implica uma contraposição à disciplina burguesa. Para ele, é necessária a construção de uma nova ordem, em que o processo de construção de uma nova cidadania corresponda ao processo de crítica e destruição da velha cidadania, da velha ordem. A nova cidadania implica chamar ao exercício da soberania estatal todos os homens, e ao exercício da soberania da produção todos os que produzem, rompendo com a cidadania baseada na quantidade abstrata e na individualidade genérica. Nesta mesma sintonia, JOSÉ WELMOWICKI expressa que a batalha contra o neoliberalismo hoje exige uma luta de classes sem trégua. Faz uma crítica à estratégia de utilizar a cidadania, nos moldes delineados pela burguesia, como proposta de defender os direitos conquistados sob esse nome, o que difundiria no movimento operário a falsa idéia de ser possível obter melhorias através da colaboração de classes, baseada numa parceria. Assim, a outra visão de cidadania, que diverge do modelo de individualismo genérico e que considera que é algo pleno e de toda a sociedade, só pode ser realmente alcançada com uma política de classe, ou seja, de uma parte desse todo que aponta uma saída anticapitalista para o conjunto. ${ }^{31}$

A constatação de uma sociedade dividida em classes não é de difícil percepção. O avanço da revolução tecnológica, a onda neoliberal que preconiza a adoção avassaladora do estado mínimo, não intervencionista e que permite que as relações sociais, de capital e trabalho, sejam reguladas pelo deus mercado. As propostas de um mercado livre com a formação de um exército reserva de mão-de-obra mantêm o dilema daqueles que estão à margem do processo produtivo, numa condição de restolho social. O crescimento do desemprego tem se agravado, e os efeitos de sua ação são dilacerantes para um significativo espectro do povo, o qual não representa o verdadeiro cidadão livre. A liberdade do desempregado é a de passar fome, ser privado dos benefícios da evolução tecnológica, ou seja, a de ser um pária social. Como ser livre nessas condições, como ser digno e decidir criticamente sobre as questões político-sociais, quando a vergonha impera em razão da sua miséria. PIERRE BOURDIEU expressa que todos os estudos científicos mostraram efetivamente que o desemprego destrói aqueles que atinge, suprime suas defesas e suas disposições subversivas. ${ }^{32}$

O crescimento do desemprego em nível mundial tem sido aventado por muitos pesquisadores como uma decorrência da revolução tecnológica, o que estaria ocasionando uma redução no nível de emprego, com a exigência de trabalhadores mais qualificados. No entanto, tais fatos, com outra roupagem, já ocorreram em tempos

30 Idem, p. 78.

31 WELMOWICKI, José. Op. cit., p. 77.

32 BOURDIEU, Pierre. Contrafogos - táticas para enfrentar a invasão neoliberal. Rio de Janeiro: Jorge Zahar, 1998, p. 128 
passados quando da implementação de novas tecnologias. O que se deve ter como claro é de que vivemos sob a égide do modelo capitalista, o qual se reproduz pelo incremento da mais-valia, conforme as lições de KARL MARX. A contradição do capital é exatamente a massa de desempregados que produz e, com a precariedade que se instala, possibilita também a revolta e o descontentamento. Assim é que se percebe a tentativa de organização da massa de desempregados, conforme o verificado em França.

PIERRE BOURDIEU, em texto sobre o movimento dos desempregados, um milagre social, realça que "a primeira conquista desse movimento é o movimento em si, a sua própria existência: ele arranca os desempregados, e com eles todos os trabalhadores precários, cujo número cresce dia a dia, da invisibilidade, do isolamento, do silêncio, em suma, da inexistência. Reaparecendo em plena luz, os desempregados reduzem à existência e a um certo orgulho todos os homens e mulheres que, como eles, o não-emprego condena habitualmente ao esquecimento e à vergonha. Mas eles lembram, sobretudo, que um dos fundamentos da ordem econômica e social é o desemprego em massa e a ameaça que ele faz pesar sobre todos os que ainda dispõem de um trabalho". ${ }^{33}$ Como ser possível o exercício da cidadania, de forma crítica e propositiva, quando se encontra marginalizado pelo sistema. A coação do desemprego produz constrangimentos que inibem a ação de quem se encontra sob a égide de uma dominação velada. Assim, como é possível imaginar que o povo esteja a caminho de uma cidadania ampliada e libertária, a não ser que seja pela luta que evidencie as diferenças sociais.

O desemprego que graça em França e demais países europeus talvez não seja tão significativo quanto o que ocorre na América Latina e África. A guerra fiscal que se instalou no Brasil, onde estados da federação se lançam a negociar junto a grandes montadoras para que estas instalem as suas fábricas em seus respectivos territórios, tem obrigado a muitos destes estados, como forma de atração, a abdicarem de boa parte dos impostos que seriam devidos. Em troca, o almejado benefício, com o incremento de um grande número de postos de trabalho, tem sido muitas vezes pífio diante da expectativa gerada, visto que boa parte da produção tem o seu processo automatizado.

A mobilidade de empresas que estavam instaladas nos grandes centros, principalmente nas regiões sul e sudeste, para regiões do norte e nordeste, ocorre em função de benefícios fiscais e de redução do preço da mão-de-obra. A falta de organização destes trabalhadores nestas regiões é um sintoma visível da baixa remuneração. A legião de desempregados, de trabalhadores precários, temporários, que assolam este país, demonstra que é extremamente difícil que, nessas condições, essa legião de indivíduos, assim considerada, pouco estímulo terá para exercer a sua cidadania. Assim, que parte do povo é esta que se encontra alijado do processo de produção e de decisão? É, no dizer de FRIEDRICH MÜLLER, “o povo ícone, erigido em sistema, induz a práticas extremadas. A iconização consiste em abandonar o povo a si mesmo; em desrealizar [entrealisieren] a população, em mitificá-la (naturalmente já não se trata há muito tempo dessa população), em hipostasiá-la de forma pseudo-sacral, tornada inofensiva para o poder-violência - notre bom peuple". ${ }^{34}$ 


\section{CONSIDERAÇÕES FINAIS}

Iniciamos este trabalho tendo por referência o art. $1^{\circ}$ da Constituição da República Federativa do Brasil, onde nos propomos a analisar de forma mais detida as concepções de povo e cidadania. A nossa preocupação foi no sentido de que, ao investigar a origem e formação de seus conceitos, pudéssemos melhor compreender a razão da inserção destes termos em nossa Carta Magna.

A nossa Constituição, denominada como cidadã, teve a pretensão de alargar o conceito de cidadania, no sentido de que o povo brasileiro fosse qualificado como cidadão, condição necessária para a participação no processo político de decisão. No entanto, passados mais de 10 anos de sua promulgação, o que se verifica é a constante depreciação deste estatuto, de seus princípios e fundamentos. Não é possível perceber o incremento de uma cidadania ampliada quando as reformas e emendas propostas visam a reduzir garantias que possibilitariam uma maior participação do povo, ou seja, do alargamento da cidadania.

A perspectiva de uma cidadania no âmbito de um Estado Democrático de Direito não pode ser aquela que ocorreu na Grécia antiga, que era concedida a uma pequena parcela da sociedade, da chamada classe dominante, os que efetivamente decidiam sobre questões sociais, políticas e jurídicas, enquanto que os estrangeiros, escravos e mulheres estavam alijados deste processo, integrando uma classe de dominados.

A cidadania que se pode vislumbrar neste país é aquela que deveria ser exercitada constantemente, exigida em todas as suas instâncias. Para isto, a organização daqueles indivíduos que se encontram isolados é fundamental para que possam participar do processo de decisão. O Estado, enquanto ente abstrato, está sujeito aos humores e ideologia do governo de plantão, o que pode redundar numa maior ou menor participação do povo enquanto cidadão. Assim, a cidadania não pode estar adstrita a expectativas ideológicas, mas, sim, ser uma conquista do povo que se torna cidadão, não por concessão, mas por obra sua.

\section{REFERÊNCIAS BIBLIOGRÁFICAS}

ARISTÓTELES. A Constituição de Atenas. Trad. e comentários de Francisco Murari Pires. São Paulo: Hucitec, 1995.

A política. Trad. Roberto Leal Ferreira. São Paulo: Martins Fontes, 1991.

AZEVEDO, Plauto Faraco de. Direito, justiça social e neoliberalismo. São Paulo: Revista dos Tribunais, 2000.

BOBBIO, Norberto. Estado, governo, sociedade - para uma teoria geral da política. 4. ed. Rio de Janeiro: Paz e Terra, 1992.

BONAVIDES, Paulo. Ciência política. 7. ed. Rio de Janeiro: Forense, 1988.

BOURDIEU, Pierre. Contrafogos - táticas para enfrentar a invasão neoliberal. Rio de Janeiro: Jorge Zahar, 1998.

DIAS, Edmundo Fernandes. Gramsci em Turim. A construção do conceito de hegemonia. São Paulo: Xamã, 2000. 
FINLEY, Moses. Democracia antiga e moderna. Trad. Waldéa Barcellos e Sandra Bedran. São Paulo: Graal, 1988.

LOCKE, John. Carta acerca da tolerância; segundo tratado sobre o governo; ensaio acerca do entendimento humano. 2. ed. Trad. Anoar Aiex e E. Jacy Monteiro. São Paulo: Abril, 1978.

MARQUES, José Luiz. Crítica das formas da modernidade. Porto Alegre: Ortiz, 1991.

. O Marxismo - passado e presente. Porto Alegre: UFRGS, 1992.

. O socialismo. Porto Alegre: UFRGS, 1991.

MCPHERSON, C. B. A teoria politica do individualismo possessivo - de Hobbes a Locke. Trad. Nelson Dantas. Rio de Janeiro: Paz e Terra, 1979.

MOREIRA NETO, Diogo de Figueiredo. Direito da participação política - legislativa, administrativa, judicial. Fundamentos e técnicas constitucionais da democracia. Rio de Janeiro: Renovar, 1992.

MÜLLER, Friedrich. Quem é o povo? A questão fundamental da democracia. Trad. Peter Naumann. São Paulo: Max Limonad, 1998.

WELMOWICKI, José. O Discurso da Cidadania e a Independência de Classe. In: Marxismo Vivo. Revista do Koorkom, jun./set. 2000, p. 66-77. 